\title{
Nāgärjuna and the Limits of Thought
}

\author{
with Graham Priest
}

If you know the nature of one thing, you know the nature of all things.

Khensur Yeshe Thubten

Whatever is dependently co-arisen,

That is explained to be emptiness.

That, being a dependent designation,

Is itself the middle way.

(MMK 24: 18)

Nagarjuna is surely one of the most difficult philosophers to interpret in any tradition. His texts are terse and cryptic. He does not shy away from paradox or apparent contradiction. He is coy about identifying his opponents. The commentarial traditions grounded in his texts present a plethora of interpretations of his view. Nonetheless, his influence in the Mahāyāna Buddhist world is not only unparalleled in that tradition but exceeds in that tradition the influence of any single Western philosopher. The degree to which he is taken seriously by so many eminent Indian, Chinese, Tibetan, Korean, Japanese, and Vietnamese philosophers, and lately by so many Western philosophers, alone justifies attention to his corpus. Even were he not such a titanic figure historically, the depth and beauty of his thought and the austere beauty of his philosophical poetry would justify that attention. While Nägãrjuna may perplex and often infuriate, and while his texts may initially defy exegesis, anyone who spends any time with Nāgārjuna's thought inevitably develops a deep respect for this master philosopher.

One of the reasons Nāgarijuna so perplexes many who come to his texts is his seeming willingness to embrace contradictions, on the one hand, while using classic reductio arguments, implicating his endorsement of the law of noncontradiction, on the other. Another reason is his apparent willingness to saw off the limbs on which he sits. He asserts that there are two truths, and that they are 
onc; that everything both exists anci does not exist; that nothing is cxistent or noncxistent; that he rejects all philosophical views including his own; that he asserts nothing. And he appears to mean every word of it. Making seise of all of this is sometimes difficult. Some interpreters of Năgāriuna, indeed, succumb to the easy temptation to read him as a simple mystic or an irrationalist of some kind. But it is significant that none of the important commentarial traditions in Asia, however much they disagree in other respects, regard him in this light.' And indeed most recent scholarship is unanimous in this regard as well, again despite a wide range of divergence in interpretations in other respects. Nägārjuna is simply too committed to rigorous analytical argument to be dismissed as a mystic.

Our interest here is neither historical nor in a systematic exegesis or assessment of any of Nagarijuna's work. Instead, we are concerned with the possibility that Nāgărjuna, like many philosophers in the West, and indeed like many of his Buddhist successors--perhaps as a consequence of his influence-discovers and explores true contradictions arising at the limits of thought. If this is indeed the case, it would account for both sides of the interpretive tension just noted: Nāgarjuna might appear to be an irrationalist in that he embraces some contradictions-both to Western philosophers and to Nyaya interlocutors who see consistency as a necessary condition of rationality. But to those who share with us a dialetheist's comfort with the possibility of true contradictions commanding rational assent, for Nāgārjuna to endorse such contradictions would not undermine but instead would confirm, the impression that he is indeed a highly rational thinker. ${ }^{2}$

We are also interested in the possibility that these contradictions are structurally analogous to those arising in the Western tradition. But while discovering a parallel between Nāgārjuna's thought and those of other paraconsistent frontiersmen such as Kant and Hegel, Heidegger and Derrida, may help Western philosophers to understand Nagariuna's project better, or at least might be a philosophical curio, we think we can deliver more than that: We will argue that while Nagaarjuna's contradictions are structurally similar to those we find in the West, Nāgãrjuna delivers a paradox as yet unknown in the West. This paradox, we will argue, brings us a new insight into ontology and into our cognitive access to the world. We should read Nägärjuna then, not because in him we can see affirmed what we already knew, but because we can learn from him.

One last set of preliminary remarks is in order. In this chapter we will defend neither the reading of Nägärjuna's texts we adopt here, nor the cogency of dialethic logic, nor the claim that true contradictions satisfying the Inclosure Schema in fact emerge at the limits of thought. We will sketch these views, but baldly, not because we take these positions to be self-evident, but because each of us has defended his respective bit of this background elsewhere. This chapter will be about bringing Nāgäriuna and dialetheism together. Finally, we do not claim that Nāgārjuna himself had explicit views about logic, or about the limits 
of thought. We do, however. think that if he did, he had the views we are about to sketch. This is, hence, not textual history but rational reconstruction.

\section{InClOSURES AND THE LIMITS OF ThOUght}

In the Tractatus, Wittgenstein takes on the project of delimiting what can be thought. He writes in the preface (trans. B. McGuiness, 1922, p. 3):

Thus the aim of the book is to draw a limit to thought, or rather-not to thought, but to the expression of thoughts: for in order to be able to draw a limit to thought, we should have to find both sides thinkable (i.e, we should have to be able to think what cannot be thought). It will therefore be only in language that the limit can be drawn, and what lies on the other side of the limit will simply be nonsense.

Yet, even having reformulated the problem in terms of language, the enterprise still runs into contradiction. In particular, the account of what can be said has as a consequence that it itself, and other things like it, cannot be said. Hence, we get the famous penultimate proposition of the Tractatus (ibid., p. 74)

My propositions serve as elucidations in the following way: anyone who understands me eventually recognizes them as nonsensical, when he has used them--as steps--to climb up beyond them. (He must, so to speak, throw away the ladder after he has climbed up it.)

Wittgenstein's predicament is serious. No matter that we throw away the ladder after we have climbed it: its rungs were nonsensical while we were using them as well. So how could it have successfully scaffolded our ascent? And if it did not, on what basis are we now to agree that all of that useful philosophy was nonsense all along? This predicament, however, is not peculiar to him. It is a quite general feature of theories that try to characterize the limits of our cognitive abilities to think, describe, grasp, that they end up implying that they themselves cannot be thought, described or grasped. Yet it would appear that they can be thought, described and grasped. Otherwise, what on earth is the theory doing?

Thus, for example, when Sextus claims in Outlines of Pyrrhonism that it is impossible to assert anything about things beyond appearances, he would seem to be asserting just such a thing; and when he argues that no assertion is justified, this must apply to his own assertion as well. When Kant says that it is impossible to know anything about, or apply any categories to, the noumenal realm, he would seem to be doing just what cannot be done. When Russell attempts to solve the paradoxes of self-reference by claiming that it is impossible to quantify over all objects, he does just that. And the list goes on. Anyone who disparages the philosophical traditions of the East on account of their supposed flirtation with paradox has a lot of the West to explain away. 
Of course, the phitosophers we just mentined were well aware of the situation, and all of them tried to take steps to avoid the contradiction. Arguably, they were not successfui. Fven more surining. Harateristically, such attempts seem to end up in other instances of the very contradictions they are trying to avoid. The recent literature surrounding the Liar Paradox provides a rich diet of such examples. ${ }^{3}$

Now, why does this striking pattern occur again and again? The simplest answer is that when people are driven to contradictions in charting the limits of thought, it is precisely because those limits are themselves contradictory. Hence, any theory of the limits that is anywhere near adequate will be inconsistent. The recurrence of the encounter with limit contradictions is therefore the basis of an argument for the best explanation of the inconsistent nature of the limits themselves. (It is not the only argument. But other arguments draw on details of the particular limits in question. ${ }^{4}$ )

The contradictions at the limits of thought have a general and bipartite structure. The first part is an argument to the effect that a certain view, usually about the nature of the limit in question, transcends that limit (cannot be conceived, described, and so on). This is Transcentence. The other is an argument to the effect that the view is within the limit-Closure. Often, this argument is practical, based on the fact that Closure is demonstrated in the very act of theorizing about the limits. At any rate, together, the pair describe a structure that can conveniently be called an inclostre: a totality, $\Omega$, and an object, 0 , such that o both is and is not in $\Omega$.

On closer analysis, inclosures can be found to have a more detailed structure. At its simplest, the structure is this. The inclosure comes with an operator, $\delta$, which, when applied to any suitable subset of $\Omega$ gives another object that is in $\Omega$ (that is, one that is not in the subset in question, but is in $\Omega$ ). Thus, for example, if we are talking about sets of ordinals, $\delta$ might apply to give us the least ordinal not in the set. If we are talking about a set of entities that have been thought about, $\delta$ might give us an entity of which we have not yet thought. The contradiction at the limit arises when $\delta$ is applied to the totality $\Omega$ itself. For then the application of $\delta$ gives an object that is both within and without $\Omega$ : the least ordinal greater than all ordinals, or the unthought object.

All of the above is catalogued in Beyont the Limits of Thought. The catalogue of limit contradictions there is not exhaustive, though. In particular, it draws only on Western philosophy. In this chapter, we will add to the list the contradictions at the limits of thought discovered by Năarjuna. As we will see, these, too, fit the familiar pattern. The fact that they do, although proceeding from a different tradition, shows that the pattern is even less parochial than one might have thought. This should not, of course, be surprising: if the limits of thought really are contradictory, then they should appear so from both east and west of the Euphrates. 
One way in which he does differ from the philosophers we have so far mentinned, though, is that Nagariuna does not try to avout the contradiction at the limits of thought. He both sees it clearly and endorses it. (In the Western tradition, few philosophers other than Hegel and some of his successors have done this.) Moreover, Nāgāiuna seems to have hit upon a limit contradiction unknown in the West, and to suggest connections between ontological and semantic contradictions worthy of attention.

\section{Conventional and Ultimate Reality}

Central to Nāgariuna's view is his doctrine of the two realities. There exist, according to Nāgārjuna, conventional reality and ultimate reality. Correspondingly, there are Two Truths: conventional truth, the truth about conventional reality; and ultimate truth, the truth about the ultimate reality-qua ultimate reality." For this reason, discussion of Nāgärjuna's view is often phrased in terms of Two Truths, rather than two realities.

The things that are conventionally true are the truths concerning the empirical world. Nägärjuna generally calls this class of truths samvrti-satya, or occasionally vyavahära-satya. The former is explained by Nāgärjuna's commentator Candrakirti as ambiguous. The first sense, the one most properly translated into English as "conventional truth (reality)" (tha snyad bden pa), is itself three ways ambiguous: on the one hand, it can mean "ordinary;" or "everyday." In this sense a conventional truth is a truth to which we would ordinarily assent, common sense augmented by good science. The second of these three meanings is "truth by agreement." In this sense, the decision in Australia to drive on the left establishes a conventional truth about the proper side of the road. A different decision in the United States establishes another. Conventional truth is, in this sense, often relative. (Candrakīrti argues that, in fact, the first sense it is also relative-relative to our sense organs, conceptual scheme, and so on. In this respect he would agree with such Pyrrhonian skeptics as Sextus.) The final sense of this cluster is "nominally true." To be true in this sense is to be true in virtue of a particular linguistic convention. So, for instance, the fact that shoes and boots are different kinds of things here but are both instances of one kind, tham in Tibetan, makes their cospecificity or lack thereof a nominal matter. We English speakers, on the other hand, regard sparrows and crows both as members of a single natural superordinate kind, bird. Native Tibetan speakers distinguish the bya (the full-sized avian) from the bya' $u$ (the smaller relative). Again, relativism about truth in this sense lurks in the background.

But these three senses cluster as one family against which stands yet another principal meaning of samurti. It can also mean "concealing," "hiding," "obscuring," "occluding." In this sense (aptly captured by the Tibetan kun rdzob bden pa, literally, "costumed truth") a samvrti-satya is something that conceals the 
truth, or its real nature, or as it is sometimes giosnce in the chaditiois, something regarded as a truth by an obscured or a deluded mind. Now, the Madhyamaka tradition, following Candrakirti, makes creative use of this ambiguity, noting that, for instance, what such truths conceal is precisely the fact that they are merely conventional (in any of the senses adumbrated above) or that an obscured mind is obscured precisely in its improper understanding of the role of convention in constituting truth, and so on.

This lexicography provides preparation for the exploration of Nāgarjuna's distinction between the conventional and the ultimate truth (reality), and between conventional and ultimate perspectives-the distinct stances Nāgarjuna distinguishes toward the world, taken by ordinary versus enlightened beings. We will thus understand the word conventional with this cluster of connotations, all present in Nāgärjuna's treatment. Our primary concern as we get to the heart of this exploration will be, however, with the notion of ultimate truth (reality) (paramartha-satya, literally, "truth of the highest meaning," or "truth of the highest object"). This we can define negatively as the way things are, considered independently of convention, or positively as the way things are, when understood by a fully enlightened being who does not mistake what is really conventional for something that belongs to the very nature of things.

What is ultimate truth/reality, according to Nägärjuna? To understand this, we have to understand the notion of emptiness, which for Nāgärjuna is emphatically not nonexistence, but, rather, interdependent existence. For something to have an essence (Tibetan, rang bzhin; Sanskrit, svabhaina) is for it to be what it is, in and of itself, independently of all other things. (This entails, incidentally, that things that are essentially so are eternally so; for if they started to be, or ceased to be, then their so being would depend on other things, such as time.) To be empty is precisely to have no essence, in this sense.

The most important ultimate truth, according to Nāgārjuna, is that everything is empty. Much of the Mülamadhyamakakärikā (henceforth $M M K$ ) consists, in fact, of an extended set of arguments to the effect that everything that one might take to be an essence is, in fact, not one-that everything is empty of essence and of independent identity. The arguments are interesting and varied, and we will not go into them here. But just to give an overview of them, a very general argument is to be found in $M M K$ 5. Here, Nagariuna argues that the spatial properties (and by analogy, all properties) of an object cannot be essential. For it would be absurd to suppose that the spatial location of an object could exist without the object itself-or, conversely, that there could be an object without location. Hence, location and object are co-dependent.

From this it follows that there is no characterized And no existing characteristic. (MMK. $5:+\mathrm{a}, \mathrm{b})$ 
The existence in question here is, of course, ultimate existence. Nāgārjuna is not denving the conventional existence of objects and their properties.

With arguments such as the preceding one, Nāgārjuna establishes that everything is empty, contingently dependent on other things - dependently co-arisen, as it is often put.

We must take the everything here very seriously, though. When Nāgärjuna claims that everything is empty, everything includes emptiness itself. The emptiness of something is itself a dependently co-arisen property of that thing. The emptiness of emptiness is perhaps one of the most central claims of the MMK." Nāgārjuna devotes much of chapter 7 to this topic. In that chapter, using some of the more difficult arguments of the $M M K$, he reduces to absurdity the assumption that dependent co-arising is itself an (ultimately) existing property of things. We will not go into the argument here, but its consequences will concern us.

For Western philosophers, it is very tempting to adopt a Kantian understanding of Nāgārjuna (as is offered, for example, by Murti 1955). Identify conventional reality with the phenomenal realm, and ultimate reality with the noumenal, and there you have it. But this is not Nāgārjuna's view. The emptiness of emptiness means that ultimate reality cannot be thought of as a Kantian noumenal realm. For ultimate reality is just as empty as conventional reality. Ultimate reality is hence only conventionally real! The distinct realities are therefore identical. As the Vimalakirtinirdesa-sütra puts it, "To say this is conventional and this is ultimate is dualistic. To realize that there is no difference between the conventional and the ultimate is to enter the Dharma-door of nonduality," or as the Heart Sutra puts it more famously, "Form is empty; emptiness is form; form is not different from emptiness; emptiness is not different from form." The identity of the Two Truths has profound soteriological implications for Nāgārjuna, such as the identity of nirvāna and samsära. ${ }^{7}$ But we will not go into these. We are now nearly in a position to address the first of Nāgārjuna's limit contradictions.

\section{NĀGĀRJUnA AND THE LAW OF NONCONTRADICTION}

One more preliminary matter remains: Nāgārjuna's attitude toward the law of noncontradiction in the domain of conventional truth. For to charge Nāgārjuna with irrationalism, or even with an extreme form of dialetheism according to which contradictions are as numerous as blackberries, is, in part, to charge him with thinking that contradictions are true in the standard conventional realm. Though this view is commonly urged (see, for example, Robinson 1957, Wood 1994), it is wrong. Though Nägärjuna does endorse contradictions, they are not of a kind that concern conventional reality, qua conventional reality.

We can get at this point in two ways: first, we can observe that Nāgärjuna himself never asserts that there are true contradictions in this realm (or, more 
cautiously, that every apparent assertion of a contradiction concerning this domain, upon analysis, resolves itself into something ase Second, we can observe that Nagarjuna takes reductio arguments to be decisive in this domain. We confess: Neither of these strategies is hermeneutically unproblematic. The first relies on careful and sometimes controversial readings of Nagāiuna's dialectic. We will argue using a couple of cases that such readings are correct. Moreover, such readings are defended in the canonical tradition by some of the greatest Mad. hyamaka exegetes.

The second strategy is difficult because, typically, Nägārjuna's arguments are directed ad hominem, against specific positions defended by his adversaries, each of whom would endorse the law of noncontradiction. If we argue that Nāgărjuna rejects the positions they defend by appealing to contradictory consequences of opponents' positions he regards as refutatory, it is always open to the irrationalist interpreter of Nagariuna to reply that for the argument to be successful one needs to regard these only as refutations for the opponent. That is, on this reading, Năgãrjuna could be taken not himself to find contradictory consequences as problematic, but to be presenting a consequence unacceptable to a consistent opponent, thereby forcing his opponent to relinquish the position on the opponent's own terms. And indeed such a reading is cogent. So if we are to give this line of argument any probative force, we will have to show that in particular cases Nägarjuna himself rejects the contradiction and endorses the conventional claim whose negation entails the contradiction. We will present such examples.

Let us first consider the claim that Nāgárjuna himself freely asserts contradictions. One might think, for instance, that when Nāgārjuna writes:

Therefore, space is not an entity.

It is not a nonentity.

Not characterized, not without character.

The same is true of the other five elements. (MMK 5:7)

he is endorsing the claim that space and the other fundamental elements have contradictory properties (existence and nonexistence, being characterized and being uncharacterized). But this reading would be pussible only if one (as we have just done) lifts this verse out of context. The entire chapter in which it occurs is addressed to the problem of reification-to treating the elements as providing an ontological foundation for all of reality, that is, as essences. After all, he concludes in the very next verse:

Fools and reificationists who perceive

The existence and nonexistence

Of objects

Do not see the pacification of objectification. ( $M M K 5: 8)$ 
It is then dear that Nagarijua is not asserting that space and the other elements have contradictory properties. Rather, he is rejecting a certain framework in which they play the role of ulimate foundations, or the role of ultimate property bearers.

Moreover, though Western and non-Buddhist Indian commentators have urged that such claims are contradictory, they are not even prima facie contradictions unless one presupposes both the law of the excluded middle and $\mathrm{Na}$ garjuna endorsement of that law. Otherwise there is no way of getting from a verse that explicitly rejects both members of the pair "Space is an entity" and "Space is a nonentity" to the claim that, in virtue of rejecting each, he is accepting its negation, and hence that he is asserting a contradiction. It is much better to read Nagariuna as rejecting excluded middle for the kind of assertion the opponent in question is making, packed as it is with what Nägärjuna regards as illicit ontological presupposition (Garfield 1995).

To consider a second example: in his discussion of the aggregates, another context in which his concern is to dispose of the project of fundamental ontology, Nāgāriuna writes:

The assertion that the effect and cause are similar

Is not acceptable.

The assertion that they are not similar

Is also not acceptable. (MMK $4: 6)$

Again, absent context, and granted the law of the excluded middle, this appears to be a bald contradiction. And again, context makes all the difference. The opponent in this chapter has been arguing that form itself (material substance) can be thought of as the cause of all psychophysical phenomena. In the previous verse Nāgārjuna has just admonished the opponent to "think about form, but / Do not construct theories about form." ( $5 \mathrm{~cd}$ ) The point of this verse is just that form, per se, is neither a plausible explanation of the material world (this would beg the question) nor of the non-material world (it fails to explain psychophysical relations). We are not concerned here with whether Nãgärjuna is right or wrong in these cases. We want to point out only that in cases like this, where it might appear that Nāgarijuna does assert contradictions, it is invariably the case that a careful reading of the text undermines the straightforwardly contradictory reading. And once again, when read with logical circumspection what we have here, in any case, is only a rejection in a particular context of the law of the excluded middle, and no warrant for moving from that rejection to any rejection of noncontradiction.

We now turn to the fact that Nāgārjuna employs reductio arguments to refute positions he rejects, showing that at least with regard to standard conventional situations, the fact that a claim entails contradictions is good reason to reject it. In chapter 15 of $M M K$, Nãgãrjuna considers the possibility that what it is to exist 
and what it is to have a particular identity is to be explained by appeal to essence. But he is able to conclude that

Those who see essence and essential difference

And entities and nonentities,

They do not see

The truth taught by the Buddha. (MMK 36: 6)

precisely on the grounds that

If there is no essence,

What could become other?

If there is essence,

What could become other? (MMK 15:9)

In this argument, lines $\mathrm{c}$ and $\mathrm{d}$-- the rest of whose detaiis, and the question of the soundness of which, we leave aside for present purposes-Nāgāijuna notes that an account of existence, change, and difference that appeals to essence leads to a contradiction. Things do "become other." That is a central thesis of the Buddhist doctrine of impermanence that Nägãrjuna defends in the text. But if they do, he argues, and if essence were explanatory of their existence, difference, and change, they would need both to have essence, to account for their existence, and to lack it, in that essences are eternal. Since this is contradictory, essence is to be rejected. And of course, as we have already noteú. Nāgärjuna does reject essence. That is the central motivation of the text.

In chapter 17 Nägärjuna responds to the opponent's suggestion that action may be something uncreated (23), a desperate ploy to save the idea that actions have essences. He responds that

All conventions would then

Be contradicted, without doubt.

It would be impossible to draw a distinction

Between virtue and evil (MMK 17: 24).

Again, neither the details of the argument nor its success concerns us here. Rather, we emphasize that, for Nāgärjuna, contradictory conseguences of positions in the standard conventional realm are fatal to those positions.

As a final example, in chapter 18 Nāgãrjuna concludis;

Whatever comes into being dependent on another

Is not identical to that thing.

Nor is it different from it.

Therefore it is neither nonexistent in time no: permanent. (MMK 18:

10) 
Here Nāgärjuna notes that the contradiction (not identical/not different) follows from the disjunction "An entity is either nonexistent or permanent" and so opts for the claim that existent phenomena are impermanent. We conclude, then, that not only does Nāgārjuna not freely assert contradictions; but when he employs them, at least when discussing standard conventional truth, he does so as the conclusions of reductio arguments, whose point is to defend the negation of the claim he takes to entail those contradictions.

At this stage, then, we draw the following conclusions: Nāgārjuna is not an irrationalist. He is committed to the canons of rational argument and criticism. He is not a mystic. He believes that reasoned argument can lead to the abandonment of error and to knowledge. He is not of the view that the conventional world, however nominal it may be, is riddled with contradictions. ${ }^{8}$ If Nāgärjuna is to assert contradictions, they will be elsewhere: defended rationally and asserted in the service of reasoned analysis.

\section{The Ultimate Truth Is That There Is No Ultimate Truth}

We are now in a position to examine Nāgājuna's first limit contradiction. The centerpiece of Nāgārjuna's Madhyamaka, or "middle way" philosophy, is the thesis that everything is empty. This thesis has a profound consequence. Ultimate truths are those about ultimate reality. But since everything is empty, there is no ultimate reality. There are, therefore, no ultimate truths. We can get at the same conclusion another way. To express anything in language is to express truth that depends on language, and so this cannot be an expression of the way things are ultimately. All truths, then, are merely conventional.

Nāgāriuna enunciates this conclusion in the following passages:

The Victorious ones have said

That Emptiness is the relinquishing of all views.

For whoever emptiness becomes a view

That one will accomplish nothing (MMK 13: 8).

I prostrate to Gautama

Who, through compassion

Taught the true doctrine

Which leads to the relinquishing of all views. (MMK 27: 30)

Nàziriuna is not saying here that one must be reduced to total silence. He himself certainly was not! The views that one must relinquish are views about the ultimate nature of reality. And there is no such thing as the ultimate nature of reality. Tha: is what it is for all phenomena to be empty.

I: might be thought that the rest is simply ineffable. Indeed, Nāgarijuna is sometimes interpreted in this way too (Gorampa 1990). But this, also, would be 
too simplistic a reading. There are ultimate truths. $M M K$ is full of them. For example, when Năgärjuna says (MMK: 24: 19):

Something that is not dependently arisen

Such a thing does not exist.

Therefore a non-empty thing

Does not exist.

he is telling us about the nature of ultimate reality. There are, therefore, ultimate truths. Indeed, that there is no ultimate reality is itself a truth about ultimate reality and is therefore an ultimate truth! This is Nāgärjuna's first limit contradiction.

There are various objections one might raise at this point in an attempt to save Nāgāruna from (ultimate) inconsistency. Let us consider wo. First, one might say that when Nagariuna appears to assert ultimate truths, he is not really asserting anything. His utterances have some other function. One might develop this point in at least two different ways. First, one may say that Nāgāriuna's speech acts are to be taken, not ats acts of assertion, but as acts of denial. It is as though, whenever someone else makes a claim about ultimate reality, Nāgärjuna simply says "No!" This is to interpret Nāgāriuna as employing a relentless via negativa. Alternatively, one may say that in these utterances Nāgărjuna is not performing a speech act at all: he is merely uttering words with no illocutionary force. In the same way, one may interpret Sextus as claiming that he, also, never made assertions: he simply uttered words, which, when understood by his opponents, would cause them to give up their views."

Whilst these strategies have some plausibility (and some ways of reading Bhāvaviveka and Candrakirti portray them as interpreting Nāgārjuna in iust this way), in the end the text simply cannot sustain this reading. There are just too many important passages in the $M M K$ in which Naagärjuna is not simply denying what his opponents say, or saying things that will cause his opponents to retract, but stating positive views of his own. Consider, for example, the central verse of the MMK:

Whatever is dependently co-arisen,

That is explained to be emptiness.

That, being a dependent designation,

Is itself the middle way. (MMK 24: 18)

Or Nāgārjuna's assertion that nirvāna and sāmnsara are identical:

Whatever is the limit of nirvaña,

That is the limit of cyclic existence.

There is not even the slightest difference between ther...

Or even the subtlest thing. (MMK 25: 20.) 
These are telling it like it is.

The stratcgy of claiming that, in the relevant portions of the text, Nāgarijuna is not making assertions gains some exegetical plausibility from the fact that sometimes Nāgãrjuna can be interpreted as describing his own utterances in this way: The locus classicus is Vigrahavyāvartani where Nãgārjuna responds to a Nyâra charge that he has undermined his own claim to the emptiness of all things through his own commitment to his assertions. In his autocommentary to verse 29, he writes:

If I had even one proposition thereby it would be just as you have said. Though if I had a proposition with the characteristic that you described, I would have that fault, I have no proposition at all. Thus, since all phenomena are empty, at peace, by nature isolated, how could there be a proposition? How can there be a characteristic of a proposition? And how can there be a fault arising from the characteristic of a proposition? Thus, the statement, "through the characteristic of your proposition you come to acquire the fault" is not true.

But context and attention to the structure of the argument make all the hermeneutic difference here. The Nyāya interlocutor has charged Nāgārjuna not simply with asserting things but with a self-refutatory commitment to the existence of convention-independent truth-makers (propositions--pratijña) for the things he say's, on pain of abandoning claims to the truth of his own theory. Naagarjuna's reply does not deny that he is asserting anything. How could he deny that? Rather, he asserts that his use of words does not commit him to the existence of any convention-independent phenomena (such as emptiness) to which those words refer. What he denies is a particular semantic theory, one he regards as incompatible with his doctrine of the emptiness of all things precisely because it is committed to the claim that things have natures (in chapter 3 of this book). Compare, in this context, Wittgenstein's rejection of the theory of meaning of the Tractatus, with its extralinguistic facts and propositions, in favor of the usetheory of the Investigations. We conclude that even the most promising textual evidence for this route to saving Nāgärjuna from inconsistency fails.

A second way one might save Nāgārjuna from inconsistency is to suggest that his asserions that appear to be statements of ultimate truth state merely conventional, and not ultimate, truths after all. One might defend this claim by pointing out that these truths can indeed be expressed, and inferring that they therefore must be conventional, for otherwise they would be ineffable. If this were so, then to say that there are no ultimate truths would simply be true, and not false. But this reacing is also hard to sustain. For something to be an ultimate truth is for it to be ine way a thing is found to be at the end of an analysis of its nature. Wher. saying tivat when we analyze that thing, looking for its essence, we literally come 
up empty. The analysis never terminates with anything that can stand as an essence. But another way of saying this is to say that the result of this uitimate analysis is the discovery that all things are empty, and that they can be no other way. 'This, hence, is an ultimate truth about them. We might point out that the Indo-Tibetan exegetical tradition, despite lots of other internecine disputes, is unanimous on this point.

There is, then, no escape. Nägärjuna's view is contradictory, "clearly a paradox of expressibility. Nāgāruna succeeds in saying the unsayable, just as much as the Wittgenstein of the Tractatus. We can think (and characterize) reality only subject to language, which is conventional, so the ontology of that reality is all conventional. It follows that the conventional objects of reality do not ultimately (nonconventionally) exist. It also follows that nothing we say of them is ultimately true. That is, all things are empty of ultimate existence; and this is their ultimate nature and is an ultimate truth about them. They hence cannot be thought to have that nature; nor can we say that they do. But we have just done so. As Mark Sid: erits $(1989$, p. 231) has put it, "The ultimate truth is that there is no ultimate truth."

\section{Positive and Negative Tetralemmas; Conventional and Ultimate Perspectives}

It may be useful to approach the contradiction at the limits of expressibility here by a different route: Nägārjuna's unusual use of both positive and negative forms of the catuhskoti, or classical Indian tetralemma. Classical Indian logic and rhetoric regards any proposition as defining a logical space involving four candidate positions, or corners (koti) in distinction to most Western logical traditions that consider only two-truth and falsity: the proposition may be true (and not false); false (and not true); both true and false; neither true nor false. As a consequence, Indian epistemology and metaphysics, including Buddhist epistemology and metaphysics, typically partitions each problem space defined by a property into four possibilities, not two." So Nāgārjuna in Mülamadhyamakakārikā considers the possibility that motion, for instance, is in the moving object, not in the moving object, both in and not in the moving object, and neither in nor not in the moving object. Each prima facie logical possibility needs analysis before rejection.

Nāgarrjuna uses both the positive and negative tetralemmas and uses the distinction in mood to differentiate between the perspectives of the Two Truths. Positive tetralemmas, such as this, are asserted from the conventional parspective:

That there is a self has been taught,

And the doctrine of no-self,

By the buddhas, as well as the

Doctrine of neither self nor non-self. (MMK 18:6) 
Some, course, interpret these as evidence for the irrationalist interpretation of Nâgaritina defused in the preceding discussion. But if we are not on the lookout for contradictory readings of this, we can see Nāgārjuna explaining simply how the policy of Two Truths works in a particular case. Conventionally, he says, there is a self-the conventional selves we recognize as persisting from day to day, such as Jay and Graham, exist. But selves do not exist ultimately. They both exist conventionally and are empty and so fail to exist ultimately-indeed, these are exactly the same thing. This verse therefore records neither inconsistency nor incompleteness: rather, it affirms the Two Truths and demonstrates that we can talk coherently about both, and about their relationship-from the conventional perspective, of course.

The distinctively Nagarjunian negative tetralemmas are more interesting. Here Nāgāruna seeks the limits of expressibility, and the contradictory situation at that limit, when we take the ultimate perspective:

"Empty" should not be asserted.

"Non-empty" should not be asserted.

Neither both nor neither should be asserted.

These are used only nominally. (MMK 22: 11)

The last line makes it clear (as does context in the text itself) that Nāgārjuna is discussing what cannot be said from the ultimate perspective-from a point of view transcendent of the conventional. And it turns out here that nothing can be said, even that all phenomena are empty, nor its negation. We can't even say that nothing can be said. But we just did. And we have thereby characterized the ultimate perspective, which, if we are correct in our characterization, cannot be done.

The relationship between these two kinds of tetralemma generates a higher order contradiction as well: they say the same thing. Each describes completely (though from different directions) the relationship between the Two Truths. The positive tetralemma asserts that conventional phenomena exist conventionally and can be characterized truly from that perspective, and that ultimately nothing exists or satisfies any description. In saying this, it in no way undermines its own cogency and in fact affirms and explains its.own expressibility. The negative counterpart asserts the same thing: that existence and characterization make sense at, and only at. the conventional level; and that, at the ultimate level, nothing exists or satisfies any description. But in doing so it contradicts itself: if true, it asserts its own nonassertability. The identity of the prima facie opposite Two Truths is curiously mirrored in the opposition of the prima facie identical two tetralemmas.

\section{Ali Things Have One Nature, That Is, No Nature}

We have examined the contradiction concerning the limits of expressibility for Nãgārjuna. Bit: as it is probably clear already, another, and more fundamental, 
contradiction underlies this, the ontological contradiction concerning emptiness itself. All things, including emptiness itself, are, as we have seen, empty. As $N \overline{\text { a }}$ gãrjuna expresses this in a verse that is at the heart of the $M M K$ :

Whatever is dependently co-arisen,

That is explained to be emptiness.

That, being a dependent designation,

Is itself the middle way. (MMK 24: 18)

Now, since all things are empty, all things lack any ultimate nature; and this is a characterization from the ultimate perspective. Thus, ultimately, things are empty. But emptiness is, by definition, the lack of any essence or ultimate nature. Nature, or essence, is just what empty things are empty of. Hence, ultimately, things must lack emptiness. To be ultimately empty is, ultimately, to lack emptiness. In other words, emptiness is the nature of all things; for this reason, they have no nature, not even emptiness. As Nāgārjuna expresses it in his autocommentary to Vigrahavyāvartani, quoting lines from the Astasahasrikaprajn̄āpāramitā-sūtra: "All things have one nature, that is, no nature."

Nãgārjuna's enterprise is one of fundamental ontology, and his conclusion is that fundamental ontology is impossible. But that is a fundamentally ontological conclusion-and that is the paradox. There is no way that things are ultimately, not even that way. The Indo-Tibetan tradition, following the Vimalakirtitirdesasütra, hence repeatedly advises one to learn to "tolerate the groundlessness of things." The emptiness of emptiness is the fact that not even emptiness exists ultimately, that it is also dependent, conventional, nominal, and in the end, it is just the everydayness of the everyday. Penetrating to the depths of being, we find ourselves back on the surface of things and so discover that there is nothing, after all, beneath those deceptive surfaces. Moreover, what is deceptive about them is simply the fact that we assume ontological depths lurking just beneath.

There are, again, ways that one might attempt to avoid the ontological contradiction. One way is to say that Nāgärjuna's utterances about emptiness are not assertions at all. We have discussed this move in connection with the previous limit contradiction. Another way, in this context, is to argue that even though Nāgärjuna is asserting that everything is empty, the emptiness in question must be understood as an accident, and not an essence, to use Aristotelian jargon. Again, though this exegetical strategy may have some plausibility, it cannot be sustained. For things do not simply happen to be empty, as some things hapf:n to be red. The arguments of $M M K$ are designed to show that all things cannot but be empty, that there is no other mode of existence of which they are capabie. Since emptiness is a necessary characteristic of things, it belongs to them esinntially-it is part of the very nature of phenomena, per se. As Candrakirti puts it, commenting on $M M K$ 13: 8: 
As it is said in the great Ratnakūta- sūtra, "Things are not empty because of emptiness; to be a thing is to be empty. Things are nol without defining characteristics through characteristiclessness; to be a thing is to be without a defining characteristic.... [W] hoever understands things in this way, Kasyapa, will understand perfectly how everything has been explained to be in the middle path.

To be is to be empty. That is what it is to be. It is no accidental property; it is something's nature - though, being empty, it has no nature.

This paradox is deeply related to the first one that we discussed. One might fairly ask, as have many on both sides of this planet, just why paradoxes of expressibility arise. The most obvious explanations might appear to be semantic in character, adverting only to the nature of language. One enamored of Tarski's treatment of truth in a formal language might, for instance, take such a route. One might then regard limit paradoxes as indicating a limitation of language, an inadequacy of a reality that must itself be consistent, and whose consistency would be mirrored in an adequate language. But Nāgārjuna's system provides an ontological explanation and a very different attitude toward these paradoxes, and hence to language. Reality has no nature. Ultimately, it is not in any way at all. So nothing can be said about it. Essencelessness thus induces noncharacterizability. But, on the other side of the street, emptiness is an ultimate character of things. And this fact can ground the (ultimate) truth of what we have just said. The paradoxical linguistic utterances are therefore grounded in the contradictory nature of reality.

We think that the Nāgãrjuna's ontological insight is distinctive of the Madhyamaka; it is hard to find a parallel in the West prior to the work of Heidegger. ${ }^{12}$ But even Heidegger does not follow Nāgărjuna all the way to the dramatic insistence on the identity of the two realities and the recovery of the authority of the conventional. This extirpation of the myth of the deep may be Naagarjuna's greatest contribution to Western philosophy.

\section{NĀGÃRIUNA AND INCLOSURE}

Everything is real and is not real, Both reai and not real,

Neither real nor not real.

This is Lord Buddha's teaching. (MMK 18: 8)

Central to Nayriuna's understanding of emptiness as immanent in the conventional worid is his doctrine of the emptiness of emptiness. That, we have seen, is what prevents the two truths from collapsing into an appearance/reality or phenomenoninomenon distinction. But it is also what generates the contradictions characterist: of philosophy at the limits. We have encountered two of these 
and have seen that they are intimately connected. The first is a paradox of expressibility: linguistic expression and conceptualization can express only conventional truth; the ultimate truth is that which is inexpressible and that which transcends these limits. So it cannot be expressed or characterized. But we have just done so. The second is a paradox of ontology: all phenomena, Nägärjuna argues, are empty and so ultimately have no nature. But emptiness is, therefore, the ultimate nature of things. So they both have and lack an ultimate nature.

That these paradoxes involve Transcendence should be clear. In the first case, there is an explicit claim that the ultimate truth transcends the limits of language and of thought. In the second case, Nagaarjuna claims that the character of ultimate reality transcends all natures. That they also involve Closure is also evident. In the first case, the truths are expressed and hence are within the limits of expressibility; and in the second case, the nature is given and hence is within the cotality of all natures.

Now consider the Inclosure Schema, introduced earlier, in a bit more detail. It concerns properties, $\varphi$ and $\psi$, and a function, $\delta$, satisfying the following conditions:

(1) $\Omega=\{\mathrm{x}: \varphi(\mathrm{x})\}$ exists, and $\psi(\Omega)$.

(2) For all $X \subseteq \Omega$ such that $\psi(X)$ :

(i) $\rightarrow \delta(X) \varepsilon X$ (Transcendence)

(ii) $\delta(X) \varepsilon \Omega$ (Closure)

Applying $\delta$ to $\Omega$ then gives $\delta(\Omega) \varepsilon \Omega$ and $\neg \delta(\Omega) \varepsilon \Omega$. In a picture, we may represent the situation thus:

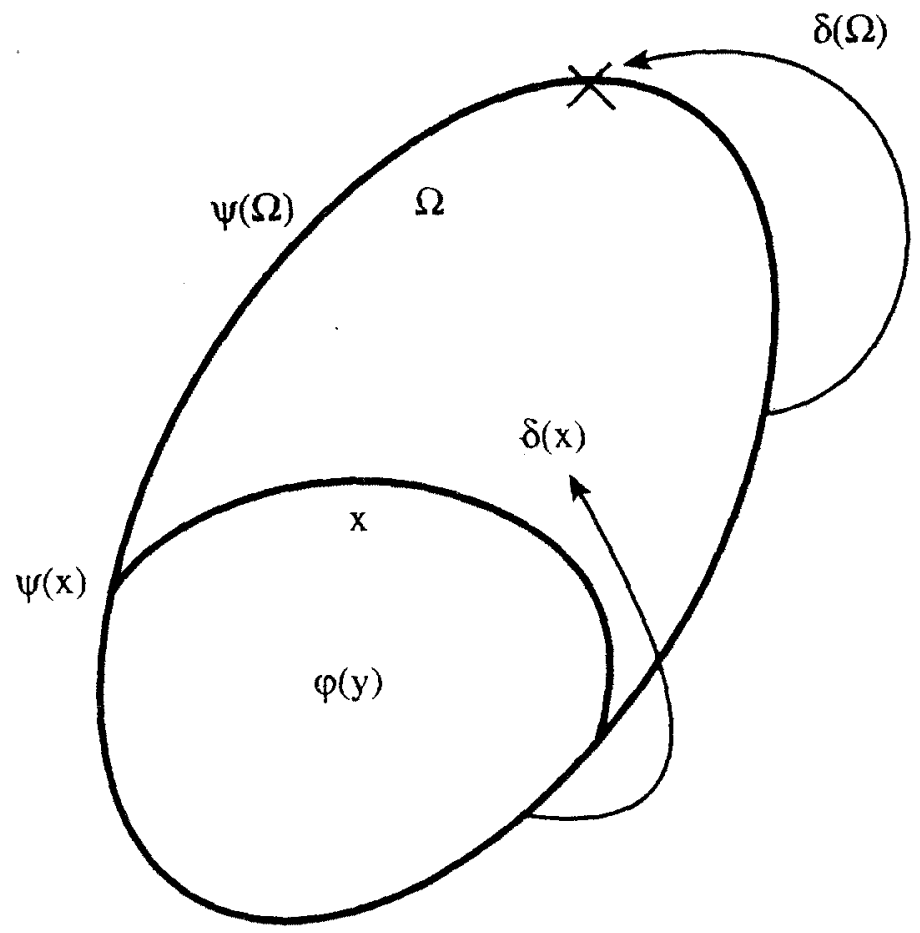


In Nāgāriuma i ontnlogical contradiction, an inclosure is formed by taking

- $\varphi(x)$ as " $x$ is empty"

- $\varphi(X)$ as " $X$ is a set of things with some common nature"

- $\delta(X)$ as "the nature of things in $X "$

To establish that this is an inclosure, we first note that $\psi(\Omega)$. For $\Omega$ is the set of things that have the nature of being empty. Now assume that $X \subseteq \Omega$ and $\psi(X)$, that is, that $X$ is a set of things with some common nature. $\delta(X)$ is that nature, and $\delta(X) \varepsilon \Omega$ since all things are empty (Closure). It follows from this that $\delta(X)$ has no nature. Hence, $\neg \delta(X) \varepsilon X$, since $X$ is a set of things with some nature (Transcendence). The limit contradiction is that the nature of all things $(\Omega)$ viz. emptiness-both is and is not empty. Or to quote Nāgārjuna, quoting the Prajñāpāramitā, "All things have one nature, that is, no nature."

In Nāgārjuna's expressibility contradiction, an inclosure is formed by taking:

- $\varphi(x)$ as " $x$ is an ultimate truth"

- $\psi(X)$ as " $X$ is definable"

- $\delta(X)$ as the sentence "there is nothing which is in $D$," where " $D$ " refers to $X$. (If $X$ is definable, there is such a $D$.)

To establish that this is an inclosure, we first note that $\psi(\Omega)$. For " $\{x: x$ is an ultimate truth\}" defines $\Omega$.

Now assume that $X \subseteq \Omega$ and $\psi(X)$, then $\delta(X)$ is a sentence that says that nothing is in X. Call this $s$. It is an ultimate truth that there are no ultimate truths, that is, that there is nothing in $\Omega$; and, since $X \subseteq \Omega$, it is an ultimate truth that there is nothing in $X$. That is, $s$ is ultimately true: $s \varepsilon \Omega$ (Closure). For Transcendence, suppose that $s \varepsilon X$. Then $s \varepsilon \Omega$, that is, $s$ is an ultimate truth, and so true, that is, nothing is in X. Hence, it is not the case that $s \in X$. The limit contradiction is that $\delta(\Omega)$, the claim that there are no ultimate truths, both is and is not an ultimate truth.

Thus, Nāgārjuna's paradoxes are both, precisely, inclosure contradictions. These contradictions are unavoidable once we see emptiness as Nāgārjuna characterizes it-as the lack of any determinate character. But this does not entail that Nāgāriuna is an irrationalist, a simple mystic, or crazy; on the contrary, he is prepared to go exactly" where reason takes him: to the transconsistent.

\section{NÁgäRJUNA's Paradox and Others LiKe AND UNLIKE IT}

Demonstrating that Nägàizina's two linked limit paradoxes satisfy a schema common to a number of weil-known paradoxes in Western philosophy (the Liar, Mirimanoff's, the Burai:-Forti, Russell's, the Knower, to name a few) goes further to normalize Nãgārjuna. ive thus encounter him as a philosopher among familiar, 
respeculib phibsophers, as a fellow traveler at the limits of epistemology and metaphysics. The air of irrationalism and laissez faire mysticism is thus dissipated once and for ail. If Nagarjula is beyond the pale, then so toe are Kant, Hegel. Wittgenstein, and Heidegger.

This tool also allows comparison between Nagariuna's insights and those of his Western colleagues, and allows us to ask what, if anything, is distinctive about his results. We suggest the following: the paradox of expressibility, while interesting and important, and crucial to Nägärjuna's philosophy of language (as well as to the development of Mahāyaña Buddhist philosophical practice throughout Central and East Asia), is not Nägärjuna's unique contribution (though he may be the first to discover and to mobilize it, which is no mean distinction in the history of philosophy). It recurs in the West in the work of Wittgenstein, Heidegger, and Derrida, to name a few, and shares a structure with such paradoxes as that of the Liar. Discovering that Năgārjuna shares this insight with many Western philosophers may help to motivate the study of Nāgarjuna by westerners, but it does not demonstrate that he has any special value to us.

The ontological paradox, on the other hand-which we hereby name Nãgärjuna's Paradox-though, as we have seen, intimately connected with a paradox of expressibility, is distinctive, and to our knowledge is found nowhere else. If Nägärjuna is correct in his critique of essence, and if it hence turns out that all things lack fundamental natures, it turns out that they all have the same nature, that is, emptiness, and hence both have and lack that very nature. This is a direct consequence of the purely negative character of the property of emptiness, a property Nägärjuna first fully characterizes, whose centrality to philosophy he first demonstrates. Most dramatically, Nāgârjuna demonstrates that the emptiness of emptiness permits the "collapse" of the distinction between the Two Truths, revealing the empty to be simply the everyday, and so saves his ontology from a simple-minded dualism. Naagarjuna demonstrates that the profound limit contradiction he discovers sits harmlessly at the heart of all things. In traversing the limits of the conventional world, there is a twist, like that in a Möbius strip, and we find ourselves to have returned to it, now fully aware of the contradiction on which it rests. ${ }^{13}$ 


\section{University Library}

\section{- M M I N E R VA A gateway to Melbourne's research publications}

Minerva Access is the Institutional Repository of The University of Melbourne

Author/s:

PRIEST, GG;GARFIELD, J

Title:

Nagarjuna and the limits of thought

Date:

2002

Citation:

PRIEST, G. G. \& GARFIELD, J. (2002). Nagarjuna and the limits of thought. GARFIELD, J (Ed.). Empty words: Buddhist philosophy and cross-cultural interpretation, (1), pp.86-105. Oxford University Press.

Persistent Link:

http://hdl.handle.net/11343/25880 